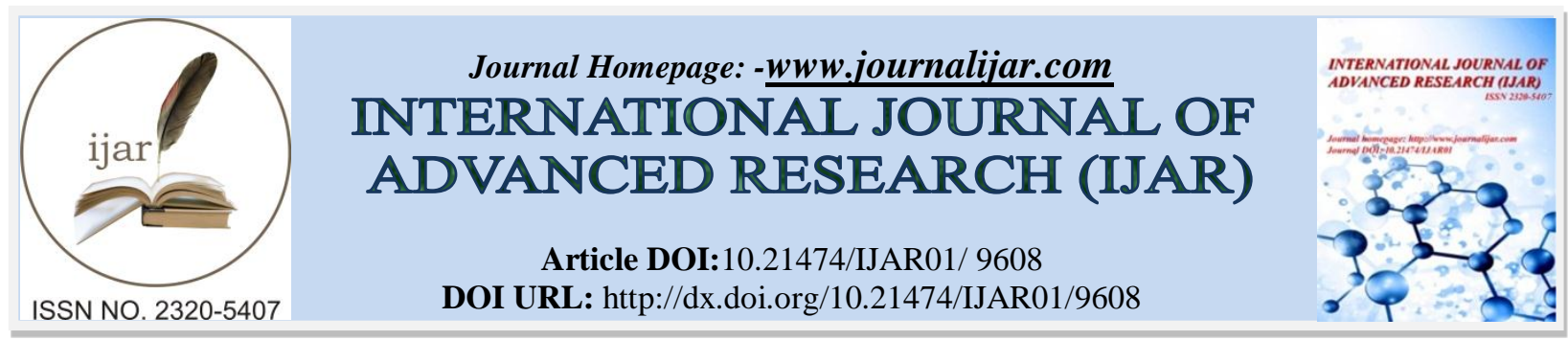

RESEARCH ARTICLE

\title{
THE ORGANIZATIONAL COMMITMENT OF EMPLOYEES IN THE HOSPITALITY INDUSTRY IN BANGKOK.
}

\author{
Nitikan Dhammahunsakul. \\ Academic Advisor, Bangkok Thai Center Co., LTDAnd Dhammahunsa Tours \& Travel Co., LTD74/4 \\ Borommaratchachonni Rd., Bangkok, Thailand.
}

\section{Manuscript Info}

Manuscript History

Received: 20 June 2019

Final Accepted: 22 July 2019

Published: August 2019

Key words:-

Organizational Commitment, Hospitality

Industry, Inspiration to Work,

Organizational Objectives.

\begin{abstract}
The purposes of this research were: 1) to study the level of organizational commitment of employees in the hospitality industry with the case study of the well-known hotels in Bangkok; 2) to find a difference in organizational commitment of employees classified by demographic profiles in the following areas: recognition in the goals and values of the organization, participation in organizational activities, inspiration to work for reaching organizational objectives, and willingness to maintain citizenship of the organization. The samples used in this study were 174 respondents. Descriptive statistics which consists of percentage, mean, and standard deviation was used in this study. Inferential statistics which consists of T-test, and One Way Analysis of Variance (ANOVA) was used to test hypotheses. The results of this study showed that, in overall, the organizational commitment of employees was at high level. In particular, inspiration to work for reaching organizational objectives had the highest mean value, followed by recognition in the goals and values of the organization, willingness to maintain citizenship of the organization, and participation in organizational activities respectively. For hypotheses testing classified by demographic profiles, the results showed that respondents with different ages, marital status, monthly income, and period of employment had difference in the overall organizational commitment at the statistical level of significance, but respondents with different gender, educational level, and position had no difference in the overall organizational commitment at the statistical level of significance.
\end{abstract}

Copy Right, IJAR, 2019,. All rights reserved.

\section{Introduction:-}

Thailand has always been a popular destination and attractive place for tourism. Nowadays, Thailand gains a large amount of income from tourism. In order to support tourism, hospitality industry is on the process of upgrading and improving its quality standard to provide satisfactory reception and welcome to many thousands of tourists each year. A number of initiatives are currently underway to upgrade the hospitality industry. The Tourism Council of Thailand (TCT) is now assessing how to narrow the gap in service charges between internationally and locally operated hotels. To address this, the Thai government is looking at introducing a new system to create a new brand of domestic hotels. The main purpose of hospitality industry is to prioritize satisfactory service and convenience to

Corresponding Author:-Nitikan Dhammahunsakul.

Address:-Academic Advisor, Bangkok Thai Center Co., LTDAnd Dhammahunsa Tours \& Travel Co., 1173 
customers who are tourists both nationally and internationally. It is different from other industries in which its business operation and benefits do not mainly depend on producing goods or selling any products, but on service and creating customer satisfaction with the main use of labor. The profit from the hospitality industry is considered as one of the main incomes of Thailand.

Hospitality industry is closely related with tourism industry. These two industries are very important which can bring foreign currency to the country, and create job employment and a large amount of income to people in Thailand. Currently, hospitality industry is growing and increasing rapidly, however, due to the political situation, and economic recession in many countries around the world, a number of tourists decrease and are not at a preferable level. Therefore, many hotels are trying to apply their strategies to better satisfy customers, and attract tourists to use their services again. They have to compete with each other to be the most well-known and well reputed in giving services to tourists. However, one of the main factors which leads to the success and growth of their businesses is mainly dependent on their employees' performance which is resulted from their organizational commitment.

Thailand always looks forward to welcoming more visitors each year. Hotels in Thailand have played an important role in the success of Thai tourism industry. However, in the current economic recession, many organizations try to save their costs by reducing some employees' welfare or by not paying some regular bonuses that employees used to receive. Some hotels may terminate the employment of their employees, which may affect the morale and organizational commitment of employees towards working in the organizations because employees feel that they have no security in jobs. The working system in hotels is the non-day off and 24 hours working. Therefore, all employees must dedicate all their efforts, strengths, and energies to work efficiently and effectively. The researcher considers organizational commitment as the important factor for employees to increase their work performance, growth and success to the hospitality industry. Therefore, the researcher conducted a research about organizational commitment of employees in the selected well-known hotels in Bangkok, Thailand.

\section{Purpose of the study}

1. To study the level of organizational commitment of employees in the selected hotels in Bangkok.

2. To find a difference of organizational commitment of respondents classified by demographic profiles in the following areas: recognition in the goals and values of the organization, participation in organizational activities, inspiration to work for reaching organizational objectives, and willingness to maintain citizenship of the organization

\section{Scope and limitation of study}

The selected well-known hotels in this research are located in the business, commercial and diplomatic district surrounded by prime shopping centers. These hotels are deluxe business hotels with resort-style facilities which are conveniently linked via Sky Bridge to two Sky Train stations and adjacent shopping and commercial buildings. The samples in this study are managers and employees of the selected hotels, starting from middle managers, manager, supervisor and employees. A total amount of the samples are 174 participants which are calculated from a total population of 307, and the formula of Taro Yamane was used as sampling technique to verify the samples.

\section{Literature Review}

\section{Concepts and Theories Associated with Organizational Commitment}

Channuwong (2016) described that organizational commitment is a positive feeling of employees towards their organization. It is considered as the most important factor for the success of the organization. Employees with high organizational commitment will dedicate their strength and effort to work for the prosperity and growth of their company. Kanter (1998) defined organizational commitment as job satisfaction that persons possess and dedicate their strength and effort to work for the growth and prosperity of the organization that they are being employed or being members. Sheldon (1991) described that organizational commitment is the positive attitude of employees towards the department or division that they are working for in which workers are committed to work for achieving the goals and objectives of organizations. Salancik (1993) stated that organizational commitment is an individual attitude and behavior presented in the way that is relevant and responded to the need of the organization. Employees who have high organizational commitment will sacrifice and work for the success of their organizations more than those with low organizational commitment. 
Porter and Smith ( referred in Channuwong, 2016) stated that organizational commitment includes the following three aspects: (a) The confidence, the belief, recognition and acceptance in the goals and values of organization; (b) The satisfaction to sacrifice all endeavors, strengths and efforts to work for reaching organizational goals; and (c) The strong willingness to maintain a good citizenship of the organization. Buchanan (1994) mentioned that organizational commitment is a close relationship or commitment that managers and employees have with their organization. Organizational commitment is a complicated attitude related to psychologies: (a) The personal feeling related to being a part of organization; and (b) The feeling of being participated in activities of organization or psychological commitment. Buchanan also pointed out that industrial psychologists have classified the causes of organizational commitment as follows: (a) Affective or attitudinal commitment. The employees will analyze structure, value, attitude, and agree with the policies of organization. This organizational commitment is strongly related with the support from organization. Therefore, such employees will have the opportunities to grow up and prosper in their organization more than the others; (b) Behavioral or continuance commitment. Employees with this commitment continue to work in the organization with the purpose to receive only some benefits such as retirement pension and other welfares. They realize that if they retire early, they cannot receive any welfare. Such employees are not participated in the values or purposes of the organization; and (c) Normative commitment. Employees who possess this commitment feel that it is their responsibility to work for their employer; they are happy to work for the company only if they see some benefits that they can receive from the company such as training in skill and knowledge, and continuing for higher education.

The organizational commitment is very important factor for all members in organizations. Employees with high organizational commitment will work effectively and sufficiently for the success, prosperity, survival of the organization. In addition, organizations must be able to select and recruit qualified employees to work in their organization, and respond to the needs of those qualified persons to maintain them to work in organization for a longer period of time. Kanter (1998) and Channuwong (2016) stated that organizational commitment is important to the business operation in the following aspects: (a) Organizational commitment can be used to predict the stabilization and resignation from job more than satisfaction because organizational commitment is more stable than job satisfaction; (b) Organizational commitment is an energy forcing employees to work for the company because they feel that they are participated in ownership of the company; (c) Organizational commitment is a connection between personal needs and objectives of the organization, (d) Organizational commitment helps employees work effectively and efficiently; and (e) Organizational commitment helps to reduce being controlled from outside because when each member has loyalty and commitment towards their organization, they will perform in the way that keep their organization in good reputation.

Liwin and Stringer (1998) described that organizational commitment leads to the effectiveness in the following aspects: (a) Employees who have real organizational commitment towards organizational objectives and values tend to be highly participated in organizational activities; (b) Employees with highly organizational commitment and belief in organizational value tend to have high inspiration to work for reaching the organizational objectives, and continue to stay longer in the company; (c) Employees with highly organizational commitment are committed to the jobs of organization because they see jobs are the factors they can work for reaching organizational goals and objectives.

Employees with highly organizational commitment are very much satisfied to spend their strength and energy to work in the organization. In many cases, they can be proved to have more work performance than the others. People work harder if pay is tied to performance. People spend more time in working when incentives are offered to them, as opposed to simply receiving base pay for the hour worked (Mathew \& Dickonson, 2000).

In return for their services, employees receive compensation, a combination of payments, benefits, and employer services. Although it isn't the only factor in motivating employees, proper compensation plays an important role in increasing organizational commitment. This can attract and retain competent and talented individuals who can help the organization accomplish its mission and goals (Kinlaw, 1999).

\section{Methodology:- \\ Data Collection Procedure and Statistical Methodology}

The researcher consulted with a couple of managers at the selected hotels in order to get some information, which were useful and meaningful to this study. Then, the research questionnaires were distributed to the respondents. In the first stage of the survey, 174 participants were identified. In the second stage, questionnaires were given to respondents known to the researcher. These persons helped the researcher pass the questionnaire to the targeted 
samples. A total of 7 questions were used to ask respondents regarding their demographic profiles, and 21 questions regarding organizational commitment were used to ask participants respectively. The survey was anonymous, using the five-point Likert Scale as responses to items regarding organizational commitment. The descriptive statistics which consists of percentage, mean, and standard deviation were used in this study. Inferential statistics which consists of T-test, and One Way Analysis of Variance (ANOVA) were used to test hypotheses.

\section{Data Analysis and Results}

This section presented the information about organizational commitment of employees based on respondents' perceptions, followed by the results of hypotheses testing regarding organizational commitment of employees classified by demographic profiles.

\section{The results of statistical analysis on organizational commitment of employees}

Table 1:-Mean and Standard Deviation of Organizational Commitment of Employees

\begin{tabular}{|l|l|l|}
\hline Organizational Commitment & Mean & Standard Deviation \\
\hline 1. Recognition in the goals and values of the organization & 3.88 & 2.43 \\
\hline 2. Participation in organizational activities & 3.49 & 1.91 \\
\hline 3. Inspiration to work for reaching organizational objectives & 3.95 & 1.96 \\
\hline 4. Willingness to maintain citizenship of the organization & 3.61 & 2.69 \\
\hline Total & \multicolumn{2}{|c|}{3.73} \\
\hline
\end{tabular}

Table 1 shows that the overall mean value of organizational commitment of employees was 3.73 (S.D. 4.50), which can be interpreted as highly committed. In particular, each aspect can also be interpreted as highly committed, which can be ranked in order from higher to lower as follows: inspiration to work for reaching organizational objectives has the highest mean value of 3.95 (S.D. 1.96), followed by recognition in the goals and values of the organization with mean value of 3.88 (S.D. 2.43), willingness to maintain citizenship of the organization with mean value of 3.61 (S.D. 2.69), and participation in organizational activities with mean value of 3.49 (S.D. 1.91) respectively.

\section{The Results of Hypothesis Testing of Organizational Commitment of Employees Classified by Demographic} Profiles

Ha1: There is a difference in organizational commitment of employees classified by genders

Table 2:-The organizational commitment of employees classified by genders

\begin{tabular}{|l|l|l|l|l|l|l|}
\hline Organizational Commitment & \multicolumn{2}{l|}{ Male } & \multicolumn{2}{l|}{ Female } & T-test & $\begin{array}{l}\text { Sig } \\
\text { (2-tailed) }\end{array}$ \\
\hline & Mean & $\begin{array}{l}\text { Standard } \\
\text { Deviation }\end{array}$ & Mean & $\begin{array}{l}\text { Standard } \\
\text { Deviation }\end{array}$ & & \\
\hline $\begin{array}{l}\text { 1. Recognition in the goals and } \\
\text { values of the organization }\end{array}$ & 3.87 & 0.41 & 3.88 & 0.408 & -.173 & 0.863 \\
\hline $\begin{array}{l}\text { 2. Participation in organizational } \\
\text { activities }\end{array}$ & 3.54 & 0.52 & 3.45 & 0.507 & 1.099 & 0.273 \\
\hline $\begin{array}{l}\text { 3. Inspiration to work for reaching } \\
\text { organizational objectives }\end{array}$ & 3.99 & 0.60 & 3.93 & 0.571 & 0.632 & 0.528 \\
\hline $\begin{array}{l}\text { 4. Willingness to maintain } \\
\text { citizenship of the organization }\end{array}$ & 3.65 & 0.60 & 3.58 & 0.524 & 0.860 & 0.391 \\
\hline Overall & 3.76 & 0.403 & 3.71 & 0.365 & 0.820 & 0.413 \\
\hline
\end{tabular}

Table 2 shows that there is no difference in organizational commitment of employees when they are classified by genders. The null hypothesis has been accepted because the sig. 2 tailed level is higher than the 0.05 level of significance. It can be interpreted that employees with different genders had no difference in organizational commitment. 
Ha2: There is a difference in organizational commitment of employees classified by ages.

Table 3:-The organizational commitment of employees classified by ages.

\begin{tabular}{|c|c|c|c|c|c|c|}
\hline $\begin{array}{l}\text { Organizational } \\
\text { Commitment }\end{array}$ & $\begin{array}{l}\text { Group } \\
\text { Variance }\end{array}$ & SS & df & MS & $\mathbf{F}$ & $\begin{array}{l}\text { Sig } \\
(2- \\
\text { tailed })\end{array}$ \\
\hline \multirow[t]{2}{*}{$\begin{array}{l}\text { 1. Recognition in the goals and values of } \\
\text { the organization }\end{array}$} & $\begin{array}{l}\text { Between group } \\
\text { Within group }\end{array}$ & $\begin{array}{l}2.084 \\
26.467\end{array}$ & $\begin{array}{l}3 \\
170 \\
\end{array}$ & $\begin{array}{l}0.695 \\
0.156\end{array}$ & $4.462 *$ & 0.005 \\
\hline & Total & 28.551 & 173 & & & \\
\hline \multirow[t]{2}{*}{ 2. Participation in organizational activities } & $\begin{array}{l}\text { Between group } \\
\text { Within group }\end{array}$ & $\begin{array}{l}1.015 \\
44.518 \\
\end{array}$ & $\begin{array}{l}3 \\
170 \\
\end{array}$ & $\begin{array}{l}0.338 \\
0.262 \\
\end{array}$ & 1.292 & 0.279 \\
\hline & & 45.553 & 173 & & & \\
\hline \multirow[t]{2}{*}{$\begin{array}{l}\text { 3. Inspiration to work for reaching } \\
\text { organizational objectives }\end{array}$} & $\begin{array}{l}\text { Between group } \\
\text { Within group }\end{array}$ & $\begin{array}{l}4.150 \\
54.063\end{array}$ & $\begin{array}{l}3 \\
170 \\
\end{array}$ & $\begin{array}{l}1.383 \\
0.318 \\
\end{array}$ & $4.350^{*}$ & 0.006 \\
\hline & & 58.214 & 173 & & & \\
\hline \multirow[t]{2}{*}{$\begin{array}{l}\text { 4. Willingness to maintain citizenship of } \\
\text { the organization }\end{array}$} & $\begin{array}{l}\text { Between group } \\
\text { Within group }\end{array}$ & $\begin{array}{l}4.444 \\
49.378\end{array}$ & $\begin{array}{l}3 \\
170\end{array}$ & $\begin{array}{l}1.481 \\
0.290\end{array}$ & $5.100 *$ & 0.000 \\
\hline & & 53.823 & 173 & & & \\
\hline \multirow[t]{2}{*}{ Overall } & $\begin{array}{l}\text { Between group } \\
\text { Within group }\end{array}$ & $\begin{array}{l}2.579 \\
22.380\end{array}$ & $\begin{array}{l}3 \\
170 \\
\end{array}$ & $\begin{array}{l}0.860 \\
0.132 \\
\end{array}$ & $6.528 *$ & 0.000 \\
\hline & Total & 24.959 & 173 & & & \\
\hline
\end{tabular}

Significant at 0.01

Table 3 shows that there is a difference in organizational commitment of employees when they are classified by different ages. The alternative hypothesis has been accepted because the sig. 2 tailed level is less than the 0.05 level of significance. It can be interpreted that employees with different age groups had a difference in organizational commitment. However, employees with different ages had no difference in organizational commitment.

Ha3: There is a difference in organizational commitment of employees classified by marital status.

Table 4:-The organizational commitment of employees classified by marital status.

\begin{tabular}{|c|c|c|c|c|c|c|}
\hline $\begin{array}{l}\text { Organizational } \\
\text { Commitment }\end{array}$ & $\begin{array}{l}\text { Group } \\
\text { Variance }\end{array}$ & SS & df & MS & $\mathbf{F}$ & $\begin{array}{l}\text { Sig } \\
(2- \\
\text { tailed) }\end{array}$ \\
\hline \multirow[t]{2}{*}{$\begin{array}{l}\text { 1. Recognition in the goals and values of } \\
\text { the organization }\end{array}$} & $\begin{array}{l}\text { Between group } \\
\text { Within group }\end{array}$ & $\begin{array}{l}2.224 \\
25.327\end{array}$ & $\begin{array}{l}3 \\
170\end{array}$ & $\begin{array}{l}1.612 \\
0.148\end{array}$ & $10.88 *$ & 0.005 \\
\hline & Total & 28.551 & 173 & & & \\
\hline \multirow[t]{2}{*}{ 2. Participation in organizational activities } & $\begin{array}{l}\text { Between group } \\
\text { Within group }\end{array}$ & $\begin{array}{l}0.418 \\
45.115\end{array}$ & $\begin{array}{l}3 \\
170\end{array}$ & $\begin{array}{l}0.209 \\
0.264\end{array}$ & 0.793 & 0.279 \\
\hline & & 45.553 & 173 & & & \\
\hline \multirow[t]{2}{*}{$\begin{array}{l}\text { Inspiration to work for reaching } \\
\text { organizational objectives }\end{array}$} & $\begin{array}{l}\text { Between group } \\
\text { Within group }\end{array}$ & $\begin{array}{l}0.600 \\
57.613\end{array}$ & $\begin{array}{l}3 \\
170\end{array}$ & $\begin{array}{l}0.300 \\
0.337\end{array}$ & $0.891 *$ & 0.006 \\
\hline & & 58.214 & 173 & & & \\
\hline \multirow[t]{2}{*}{$\begin{array}{l}\text { 4. Willingness to maintain citizenship of } \\
\text { the organization }\end{array}$} & $\begin{array}{l}\text { Between group } \\
\text { Within group }\end{array}$ & $\begin{array}{l}4.536 \\
49.378\end{array}$ & $\begin{array}{l}3 \\
170\end{array}$ & $\begin{array}{l}2.268 \\
0.288\end{array}$ & $7.869 *$ & 0.000 \\
\hline & & 53.823 & 173 & & & \\
\hline \multirow[t]{2}{*}{ Overall } & $\begin{array}{l}\text { Between group } \\
\text { Within group }\end{array}$ & $\begin{array}{l}1.187 \\
23.471\end{array}$ & $\begin{array}{l}3 \\
170\end{array}$ & $\begin{array}{l}0.744 \\
0.137\end{array}$ & $5.418 *$ & 0.000 \\
\hline & Total & 24.959 & 173 & & & \\
\hline
\end{tabular}

Significant at 0.01

Table 4 shows that there is a difference in organizational commitment of employees when they are classified by different marital status. The alternative hypothesis has been accepted because the sig. 2 tailed level is less than the 0.05 level of significance. It can be interpreted that employees with different marital status had a difference in 
organizational commitment. However, employees with different marital status had no difference in organizational commitment.

Ha4: There is a difference in organizational commitment of employees classified by educational levels.

Table 5:-The organizational commitment of employees classified by educational levels.

\begin{tabular}{|c|c|c|c|c|c|c|}
\hline $\begin{array}{l}\text { Organizational } \\
\text { Commitment }\end{array}$ & $\begin{array}{l}\text { Group } \\
\text { Variance }\end{array}$ & SS & df & MS & $\mathbf{F}$ & $\begin{array}{l}\text { Sig } \\
\text { (2- } \\
\text { tailed) }\end{array}$ \\
\hline \multirow[t]{2}{*}{$\begin{array}{l}\text { 1. Recognition in the goals and values of } \\
\text { the organization }\end{array}$} & $\begin{array}{l}\text { Between group } \\
\text { Within group }\end{array}$ & $\begin{array}{l}0.240 \\
28.311\end{array}$ & $\begin{array}{l}4 \\
169\end{array}$ & $\begin{array}{l}0.060 \\
0.168\end{array}$ & 0.358 & 0.838 \\
\hline & Total & 28.551 & 173 & & & \\
\hline \multirow[t]{2}{*}{ 2. Participation in organizational activities } & $\begin{array}{l}\text { Between group } \\
\text { Within group }\end{array}$ & $\begin{array}{l}1.988 \\
43.545\end{array}$ & $\begin{array}{l}4 \\
169 \\
\end{array}$ & $\begin{array}{l}0.497 \\
0.258\end{array}$ & 1.929 & 0.108 \\
\hline & & 45.553 & 173 & & & \\
\hline \multirow[t]{2}{*}{$\begin{array}{l}\text { 3. Inspiration to work for reaching } \\
\text { organizational objectives }\end{array}$} & $\begin{array}{l}\text { Between group } \\
\text { Within group }\end{array}$ & $\begin{array}{l}0.317 \\
57.897 \\
\end{array}$ & $\begin{array}{l}4 \\
169 \\
\end{array}$ & $\begin{array}{l}0.079 \\
0.337 \\
\end{array}$ & 0.231 & 0.921 \\
\hline & & 5.214 & 173 & & & \\
\hline \multirow[t]{2}{*}{$\begin{array}{l}\text { 4. Willingness to maintain citizenship of } \\
\text { the organization }\end{array}$} & $\begin{array}{l}\text { Between group } \\
\text { Within group }\end{array}$ & $\begin{array}{l}2.155 \\
51.667 \\
\end{array}$ & $\begin{array}{l}4 \\
169 \\
\end{array}$ & $\begin{array}{l}2.268 \\
0.288 \\
\end{array}$ & 1.762 & 0.139 \\
\hline & & 53.823 & 173 & & & \\
\hline \multirow[t]{2}{*}{ Overall } & $\begin{array}{l}\text { Between group } \\
\text { Within group }\end{array}$ & $\begin{array}{l}0.614 \\
24.344\end{array}$ & $\begin{array}{l}4 \\
169 \\
\end{array}$ & $\begin{array}{l}0.744 \\
0.137\end{array}$ & 1.066 & 0.375 \\
\hline & Total & 24.959 & 173 & & & \\
\hline
\end{tabular}

Significant at 0.01

Table 5 shows that there is no difference in organizational commitment of employees when they are classified by different educational levels. The null hypothesis has been accepted because the sig.2 tailed level is higher than the 0.05 level of significance. It can be interpreted that employees with different educational levels had no difference in organizational commitment.

Ha5: There is a difference in organizational commitment of employees classified by monthly income.

Table 6:-The organizational commitment of employees categorized by monthly income.

\begin{tabular}{|c|c|c|c|c|c|c|}
\hline $\begin{array}{l}\text { Organizational } \\
\text { Commitment }\end{array}$ & $\begin{array}{l}\text { Group } \\
\text { Variance }\end{array}$ & SS & df & MS & $\mathbf{F}$ & $\begin{array}{l}\text { Sig } \\
(2- \\
\text { tailed })\end{array}$ \\
\hline \multirow[t]{2}{*}{$\begin{array}{l}\text { 1. Recognition in the goals and values of } \\
\text { the organization }\end{array}$} & $\begin{array}{l}\text { Between group } \\
\text { Within group }\end{array}$ & $\begin{array}{l}0.646 \\
27.905\end{array}$ & $\begin{array}{l}3 \\
170\end{array}$ & $\begin{array}{l}0.215 \\
0.164\end{array}$ & 1.311 & 0.273 \\
\hline & Total & 28.551 & 173 & & & \\
\hline \multirow[t]{2}{*}{ 2. Participation in organizational activities } & $\begin{array}{l}\text { Between group } \\
\text { Within group }\end{array}$ & $\begin{array}{l}2.494 \\
43.039 \\
\end{array}$ & $\begin{array}{l}3 \\
170\end{array}$ & $\begin{array}{l}0.831 \\
0.253\end{array}$ & $3.284 *$ & 0.022 \\
\hline & & 45.553 & 173 & & & \\
\hline \multirow[t]{2}{*}{$\begin{array}{l}\text { 3. Inspiration to work for reaching } \\
\text { organizational objectives }\end{array}$} & $\begin{array}{l}\text { Between group } \\
\text { Within group }\end{array}$ & $\begin{array}{l}3.185 \\
55.209\end{array}$ & $\begin{array}{l}3 \\
170\end{array}$ & $\begin{array}{l}1.062 \\
0.324\end{array}$ & $3.280 *$ & 0.022 \\
\hline & & 58.214 & 173 & & & \\
\hline \multirow[t]{2}{*}{$\begin{array}{l}\text { 4. Willingness to maintain citizenship of } \\
\text { the organization }\end{array}$} & $\begin{array}{l}\text { Between group } \\
\text { Within group }\end{array}$ & $\begin{array}{l}6.917 \\
46.905\end{array}$ & $\begin{array}{l}3 \\
170\end{array}$ & $\begin{array}{l}2.306 \\
0.276\end{array}$ & $8.357 *$ & 0.000 \\
\hline & & 53.823 & 173 & & & \\
\hline \multirow[t]{2}{*}{ Overall } & $\begin{array}{l}\text { Between group } \\
\text { Within group }\end{array}$ & $\begin{array}{l}2.575 \\
22.384\end{array}$ & $\begin{array}{l}3 \\
170\end{array}$ & $\begin{array}{l}0.858 \\
0.132\end{array}$ & $6.519 *$ & 0.000 \\
\hline & Total & 24.959 & 173 & & & \\
\hline
\end{tabular}

Significant at 0.01

Table 6 that there is a difference in organizational commitment of employees when they are classified by different monthly income. The alternative hypothesis has been accepted because the sig. 2 tailed level is less than the 0.05 level of significance. It can be interpreted that employees who have different monthly income had difference in the 
overall organizational commitment. However, employees who have different monthly income had no different organizational commitment in terms of recognition in the goals and values of the organization.

Ha6: There is a difference in organizational commitment of employees classified by different positions.

Table 7:-The organizational commitment of employees classified by positions.

\begin{tabular}{|c|c|c|c|c|c|c|}
\hline $\begin{array}{l}\text { Organizational } \\
\text { Commitment }\end{array}$ & $\begin{array}{l}\text { Group } \\
\text { Variance }\end{array}$ & SS & df & MS & F & $\begin{array}{l}\text { Sig } \\
\text { (2- } \\
\text { tailed) }\end{array}$ \\
\hline \multirow[t]{2}{*}{$\begin{array}{l}\text { 1. Recognition in the goals and values of } \\
\text { the organization }\end{array}$} & $\begin{array}{l}\text { Between group } \\
\text { Within group }\end{array}$ & $\begin{array}{l}0.450 \\
28.101\end{array}$ & $\begin{array}{l}2 \\
171\end{array}$ & $\begin{array}{l}0.225 \\
0.164\end{array}$ & 1.370 & 0.257 \\
\hline & Total & 28.551 & 173 & & & \\
\hline \multirow[t]{2}{*}{$\begin{array}{l}\text { 2. Participation in organizational } \\
\text { activities }\end{array}$} & $\begin{array}{l}\text { Between group } \\
\text { Within group }\end{array}$ & $\begin{array}{l}1.696 \\
43.838\end{array}$ & $\begin{array}{l}2 \\
171\end{array}$ & $\begin{array}{l}0.848 \\
0.256\end{array}$ & $3.307 *$ & 0.039 \\
\hline & & 45.553 & 173 & & & \\
\hline \multirow[t]{2}{*}{$\begin{array}{l}\text { 3. Inspiration to work for reaching } \\
\text { organizational objectives }\end{array}$} & $\begin{array}{l}\text { Between group } \\
\text { Within group }\end{array}$ & $\begin{array}{l}0.409 \\
57.805\end{array}$ & $\begin{array}{l}2 \\
171\end{array}$ & $\begin{array}{l}0.205 \\
0.338\end{array}$ & 0.605 & 0.547 \\
\hline & & 58.214 & 173 & & & \\
\hline \multirow[t]{2}{*}{$\begin{array}{l}\text { 4. Willingness to maintain citizenship of } \\
\text { the organization }\end{array}$} & $\begin{array}{l}\text { Between group } \\
\text { Within group }\end{array}$ & $\begin{array}{l}0.658 \\
53.165\end{array}$ & $\begin{array}{l}2 \\
171\end{array}$ & $\begin{array}{l}0.329 \\
0.311\end{array}$ & 1.058 & 0.349 \\
\hline & & 53.823 & 173 & & & \\
\hline \multirow[t]{2}{*}{ Overall } & $\begin{array}{l}\text { Between group } \\
\text { Within group }\end{array}$ & $\begin{array}{l}0.452 \\
24.507\end{array}$ & $\begin{array}{l}2 \\
171\end{array}$ & $\begin{array}{l}0.226 \\
0.143\end{array}$ & 1.576 & 0.210 \\
\hline & Total & 24.959 & 173 & & & \\
\hline
\end{tabular}

*Significant at 0.01

Table 7 shows that there is no difference in organizational commitment of employees when they are classified by positions. The null hypothesis has been accepted because the sig. 2 tailed level is higher than the 0.05 level of significance. It can be interpreted that employees who have different positions had no difference in the overall organizational commitment. In particular, the results of statistical analysis show that employees with different positions had different organizational commitment in terms of participation in organizational activities.

Ha7: There is a difference in organizational commitment of employees classified by period of job employment.

Table 8:-The organizational commitment of employees classified by period of job employment.

\begin{tabular}{|c|c|c|c|c|c|c|}
\hline $\begin{array}{l}\text { Organizational } \\
\text { Commitment }\end{array}$ & $\begin{array}{l}\text { Group } \\
\text { Variance }\end{array}$ & SS & df & MS & $\mathbf{F}$ & $\begin{array}{l}\text { Sig } \\
(2- \\
\text { tailed })\end{array}$ \\
\hline \multirow[t]{2}{*}{$\begin{array}{l}\text { 1. Recognition in the goals and values of } \\
\text { the organization }\end{array}$} & $\begin{array}{l}\text { Between group } \\
\text { Within group }\end{array}$ & $\begin{array}{l}2.020 \\
226.531\end{array}$ & $\begin{array}{l}3 \\
170\end{array}$ & $\begin{array}{l}0.673 \\
0.156\end{array}$ & $4.314 *$ & 0.006 \\
\hline & Total & 28.551 & 173 & & & \\
\hline \multirow[t]{2}{*}{ 2. Participation in organizational activities } & $\begin{array}{l}\text { Between group } \\
\text { Within group }\end{array}$ & $\begin{array}{l}2.139 \\
43.395\end{array}$ & $\begin{array}{l}3 \\
170\end{array}$ & $\begin{array}{l}0.713 \\
0.255\end{array}$ & $2.793 *$ & 0.042 \\
\hline & & 45.553 & 173 & & & \\
\hline \multirow[t]{2}{*}{$\begin{array}{l}\text { 3. Inspiration to work for reaching } \\
\text { organizational objectives }\end{array}$} & $\begin{array}{l}\text { Between group } \\
\text { Within group }\end{array}$ & $\begin{array}{l}2.937 \\
55.277\end{array}$ & $\begin{array}{l}3 \\
170\end{array}$ & $\begin{array}{l}0.979 \\
0.325\end{array}$ & $3.010^{*}$ & 0.032 \\
\hline & & 58.214 & 173 & & & \\
\hline \multirow[t]{2}{*}{$\begin{array}{l}\text { 4. Willingness to maintain citizenship of } \\
\text { the organization }\end{array}$} & $\begin{array}{l}\text { Between group } \\
\text { Within group }\end{array}$ & $\begin{array}{l}8.405 \\
45.417\end{array}$ & $\begin{array}{l}3 \\
170\end{array}$ & $\begin{array}{l}2.802 \\
0.267\end{array}$ & $10.49 *$ & 0.000 \\
\hline & & 53.823 & 173 & & & \\
\hline \multirow[t]{2}{*}{ Overall } & $\begin{array}{l}\text { Between group } \\
\text { Within group }\end{array}$ & $\begin{array}{l}2.814 \\
22.145\end{array}$ & $\begin{array}{l}3 \\
170\end{array}$ & $\begin{array}{l}0.938 \\
0.130\end{array}$ & $7.200 *$ & 0.000 \\
\hline & Total & 24.959 & 173 & & & \\
\hline
\end{tabular}

*Significant at 0.01

Table 8 shows that there is a difference in organizational commitment of employees when they are classified by different period of job employment. The alternative hypothesis has been accepted because the sig. 2 tailed level is 
less than the 0.05 level of significance. It can be interpreted that employees with different period of job employment had difference in the overall organizational commitment.

\section{Conclusion from the Findings:- Demographic Profile}

A total number of respondents who completed the questionnaires were 174 samples. As for gender, there were $61.49 \%$ or 107 female respondents. The other $38.51 \%$ or 67 respondents were male. The results show that a majority of respondents were female. The majority of respondents were aged between 25-35 years old, presented by $45.98 \%$. The minority of respondents were aged at 46 years old and older, presented by $8.04 \%$. As for marital status, the majority of respondents were single with $47.70 \%$. The minority of respondents were divorced with $6.90 \%$. As for educational level, the majority of respondents received Bachelor's degree and higher with $32.76 \%$, while $29.31 \%$ finished senior high school, $21.26 \%$ finished junior high school, and only $16.67 \%$ finished certificate below Bachelor degree. As for monthly income, the majority of respondents received monthly income from 10,001 to 25,000 baht with $54.02 \%$, while $36.78 \%$ received monthly income less than 10,000 baht, 5.75\% received 25,00135,000 baht, and only $3.45 \%$ received 35,001 baht and above. As for position, the majority of respondents were Kitchen service / food beverage service, and house keeping with $51.72 \%$, while the minority of respondents were Front office, host, and receptionist with $11.50 \%$. As for period of job employment, the majority of respondents have been working from 1 to 4 years with 35.63\%, whereas the minority of respondents have been working from 5 to 10 years.

\section{Organizational Commitment of Employees}

The overall organizational commitment of employees at the selected hotels had the mean value of 3.73, which can be interpreted as highly committed. In particular, it was found that each aspect of organizational commitment can also be interpreted as highly committed, which can be ranked in order from higher to lower as follows: inspiration to work for reaching organizational objectives had the mean value of 3.95, followed by recognition in the goals and values of the organization with mean value of 3.88 , willingness to maintain citizenship of the organization with mean value of 3.61, and participation in organizational activities with mean value of 3.41 respectively.

\section{Hypotheses Testing}

The purpose of this section is to compare employees' organizational commitment classified by gender, age, marital status, levels of education, monthly income, position, and period of job employment. From statistical analysis, it was found that employees with different gender, levels of education, and position had no significantly difference in the overall organizational commitment, whereas employees with different age group, marital status, and period of job employment had significantly difference in the overall organizational commitment.

\section{Implications of the Study}

The results of the study showed that most of respondent are female with ages between 25-35 years old. A majority of them are single, graduated Bachelor's Degree, and have monthly income from 10,001-25,000 baht. The implication from this study can be explained as follows: The first implication showed that there is an increasing number of women working in the hospitality industry; women have equal opportunity to work in the company. The second implication showed that there is a higher trend for employees to be single due the economic situation. Most of employees may think that they are not ready to get married, or some may think that if they are married, they may not able to take care of their family. Therefore, they prefer to stay single with less family responsibility. The third implication showed that the level of education is very important for working in any company; Bachelor Degree becomes the basic requirement for selecting and recruiting employees to work in the company. People with educational level lower than Bachelor's Degree tend to be difficult to get a job in the future. The fourth implication showed that employees who hold a Bachelor's Degree choose to work in an organization that offers them monthly income up to 15,000 Baht in order to cover the cost of living that is increasing rapidly. The fifth implication showed that employees had the highest level of organizational commitment in terms of inspiration to work for achieving organizational goals. This means that most of employees are inspired to work for the success and growth of the organization. However, some may have less participation in organizational activities. 


\section{Limitations and Recommendations:-}

The present study focuses on the organizational commitment of employees at the selected hotels in Bangkok. The researcher would like to suggest that it would be useful to compare the level of organizational commitment between employees working in hotels in Bangkok and outside of Bangkok.

This study focuses on the employees' organizational commitment in the following areas: recognition in the goals and values of the organization, participation in organizational activities, inspiration to work for reaching organizational objectives, and willingness to maintain citizenship of the organization, the researcher would like to suggest that future research should focus on more than these areas and the samples should be expanded to other cities and provinces.

\section{References:-}

1. Buchanan, B. (1994). Building organization commitment: The socialization of managers in work organization. Administrative Science Quaterly.5:352-358.

2. Channuwog, S. (2016). Organizational commitment of university staff and lecturers: A case study of Mahamakut Buddhist University. Journal of Community Development Research, 8(3): 34-46.

3. Kanter, R.M. (1998). Commitment and social organization: A student of commitment mechanisms in Utopia community. American Sociological Review. 33: 490-499

4. Kinlaw, C. (1999). What employees see is what organization gets. ManagementSolutions, 3, 38-41.

5. Lawler, E. (2002). Pay and development. Boston: Addison-Wesley.

6. Mathew, G.A.\& Dickinson, M. (2000). The effects of alternative activities on time allocated to task performance under different percentage of incentive pay. Journal of Organizational Behavior Management, 33:34-38.

7. Mathis, R., \& Jackson, H. (2000). Human resource management: Formal downward communication. New York: West Publishing.

8. Milkovich, G.T. (2002). Personnel human resource management. Homewood, IL: Business Publication.

9. Salansick, G.R. (1993). Commitment and the control of organization behavior and belief in Psychological foundation of organization behavior $2^{\text {nd }}$ edition. Barry M. Staw Scott, Foreman Company.

10. Sheldon, M.E. (1991). Investment and involvements as mechanism producing commitment to the organization. Administrative Science Quarterly: 23:143-146.

11. Liwin G. and Stringer R. (1998). Motivation and organizational climate. Massachusetts: Harvard University Press. 